http://kitaibelia.unideb.hu/

ISSN 2064-4507 (Online) • ISSN 1219-9672 (Print)

(C) Department of Botany, University of Debrecen, Hungary

25(1): 19-26.; 2020

DOI: $10.17542 /$ kit.25.19

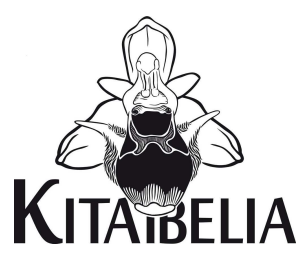

\title{
A csókalábú útifú (Plantago coronopus) folytatódó térhódítása Magyarországon
}

\author{
SCHMIDT Dávid ${ }^{1 *}$, BAUER Norbert² ${ }^{2}$ FEKETE Réka ${ }^{3}$, HASZONITS Győző ${ }^{1}$, \\ SÜVEGES Kristóf ${ }^{3}$ \& MOLNÁR V. Attila ${ }^{3}$ \\ (1) Soproni Egyetem, EMK, Növénytani és Természetvédelmi Intézet, \\ H-9400 Sopron, Bajcsy-Zsilinszky u. 4.; *schmidt.david@uni-sopron.hu \\ (2) Magyar Természettudományi Múzeum, Növénytár, H-1089, Budapest, Könyves K. krt. 40.
}

(3) Debreceni Egyetem TTK Növénytani Tanszék, H-4032 Debrecen, Egyetem tér 1.

\section{Continuing spread of Plantago coronopus along Hungarian roads}

\begin{abstract}
In the course of our research of Hungarian transport routes, we observed an intensive spread of the Atlantic-Mediterranean Plantago coronopus L., a recently established species in Hungary. Between 2017 and 2019, it was detected in 47 flora mapping quadrats, which increased the total number of occurrences to 81 since 2013. Besides motorways, the main Hungarian transport routes were involved as well. 26 occurrences have been recorded along the roads 4/E60, E573, 8/E66, 86/E65 and 87, which are severely affected by international traffic. However, on routes avoiding international transit traffic, the species' occurrences are still rare. In some cases, the predominant direction of traffic appeared to influence the formation of new stands. It is very likely that the first individuals that appeared along the section of the M86/E65 motorway between Szombathely and Hegyfalu in 2019 , arrived primarily by northbound traffic, rather than along the road 86, which runs parallel to it only a few hundred meters away. Likewise, it seems certain that the spread of the species along the roads M1/E60, E75 (Mocsa, Tata, Páty) and M7/E71 (Fonyód, Balatonlelle, Kajászó) as well as the road 8/E66 (Bakonygyepes, Veszprém) is due to reproduction of older extensive local populations. At several localities along the outer bend of roundabouts or near the exits of motorways, a dispersal role of intense winter road salting was also observed. The largest populations were located mostly along ditches, next to the (often bare) lane of roadbeds that are heavily affected by mechanical and osmotic stress. The majority of stands were found within a 3 meters wide belt along the asphalt strip (5 meters was measured in the lawn of a cemetery once). Since the species is present continuously at several localities since 2013, it is considered as naturalised in Hungary, and its further spread can be confidently predicted. The current status of the species in Hungary is naturalised (non-transformer) neophyte.
\end{abstract}

Keywords: flora mapping, naturalization, road ecology, routes

Összefoglalás - Magyarországi úthálózat vizsgálata során az atlanti-mediterrán elterjedésű Plantago coronopus L. intenzív terjedését tapasztaltuk. 2017-2019 között a fajt újabb 47 flóratérképezési kvadrátból mutattuk ki, amellyel 81-re nőtt előfordulásainak száma. Kimutattuk, hogy a gyorsforgalmi utak mellett a faj erős terjedése a főközlekedési utakat is elérte, ezen kívüli megjelenései egyelőre ritkák. Legnagyobb kiterjedésű és egyedsűrűségű állományai az útpadkák mechanikus és ozmotikus stressztől erősebben érintett (gyakran növényzetmentes) sávja mögötti részén találhatók, de néhány előfordulás ilyen helyeken kívül is ismert. 2013-tól ismert állományai közül több helyen ma is összefüggő tömegben van jelen, így a faj egyértelmúen meghonosodott (de nem átalakító) neofitonnak tekinthető.

Kulcsszavak: flóratérképezés, meghonosodás, úthálózat, útökológia 


\section{Bevezetés}

A közlekedési rendszerek (út- és vasúthálózatok) világszerte egyre jelentősebb szerepet töltenek be a fajok terjesztésében (FORMAN et al. 2003, GELBARD \& BELNAP 2003, VAN DER REE et al. 2015). Egyes növényfajok szokatlanul gyors terjedéséről utak mentén Közép-Európából is emelkedő számú publikáció számol be (pl. KirÁly \& HoHla 2015, DíTĚ \& DíTĚTovÁ 2016, FEKETE et al. 2018). Hazánkban az egyik legsikeresebben terjedő fajnak az atlanti-mediterrán elterjedésű csókalábú útifű (Plantago coronopus L.) tűnik. A faj első ízben 2013. szeptember 13-án került elő az M1-es autópálya Győrt elkerülő szakaszáról. Felfedezését számos további állomány megtalálása követte, köszönhetően a gyorsforgalmi utak célzott átvizsgálásának. A 2013-2016 közötti időszakban 30 település határában, összesen 35 flóratérképezési kvadrátban vált ismertté (SCHMIDT et at. 2016). Jelen közlemény célja a faj terjedésével kapcsolatos újabb adatok, eredmények bemutatása, hazai elterjedési mintázatának térképen való ábrázolása. Terjedésének hátterével, dinamikájával, ökológiájával ugyanakkor itt nem foglalkozunk, ezeket egy későbbi dolgozatban kívánjuk tárgyalni.

\section{Anyag és módszer}

Vizsgálatainkat 2017-2019 között végeztük Magyarország közúthálózatán. A kiemelt nemzetközi forgalmat bonyolító gyorsforgalmi úthálózat (autóutak, autópályák) mellett célzottan vizsgáltuk az elsőrendű és másodrendű fôútvonal-hálózatot. Egyéb utakon alkalmankénti, pontszerű mintavétel történt. A vizsgálatba vont utak száma 18, amelyek közül 4 autópálya, 3 autóút, 4 elsőrendű fő́t, 7 másodrendű főút. A Plantago coronopus megtalált populációinak helyét WGS-koordinátával jelöltük meg, az adatokat adatbázisba rendeztük. A faj előfordulási adatait a közép-európai flóratérképezési hálórendszer (NIKLFELD 1971) alapmezőinek negyedelésével kapott kvadrátok kódjaival láttuk el és ez alapján összegeztük.

\section{Eredmények és értékelésük}

\section{Általános kép, terjedés}

A faj igen gyors terjedését bizonyítja, hogy 2017-2019 között újabb 47 flóratérképezési alapmező-negyedben mutattuk ki (kvadrátonként egy vagy több) új előfordulását, aktuálisan 81 kvadrátból ismert (1. ábra).

Előfordulásai kezdetben többnyire autópályák (2013-től az M1-es és M70-es, 2015-től az M7-es, 2016-tól az M3-as és M5-ös) pihenőhelyeihez, forgalmi csomópontjainak útpadkáihoz kötődtek. Emellett már 2014-től kezdődően megjelentek állományai a gyorsforgalmi úthálózaton kívüli (elsőrendű és másodrendű főközlekedési) utak szegélyéről (Veresegyház, Fertőszentmiklós, Szombathely környéke), valamint bevásárlóközpontok környékéről (Csömör, Budakalász) (SCHMIDT et at. 2016). 2017-től ugrásszerűen megszaporodtak autópályát elhagyó populációi, különösen a 86-os és 8-as főutak Vas megyei szakaszának útpadkáin találtuk meg helyenként összefüggő tömegben (SCHMIDT 2019). Kijelenthető, hogy a faj hazánkban már nem csak a zárt pályarendszerű gyorsforgalmi úthálózaton belül képes a hatékony terjedésre.

Jelenleg ismert előfordulásainak 7,4 \%-a magyarországi kódolás szerinti egy- és kétszámjegyü főutak hálózatán kívül, alsóbbrendű utak mellett található. Ez a megfigyelés párhuzamban van a hazánktól nyugatra fekvő országokban újabban tapasztalt folyamattal, ahol a faj szintén megjelent a gyorsforgalmi úthálózaton kívüli antropogén élőhelyeken, főként alsóbbrendű utakon (HoHLA 2018, KAPLAN et al. 2018, EHL et al. 2019). A P. coronopus előfordulásait a hazai közúthálózaton a 2. ábra mutatja be. 


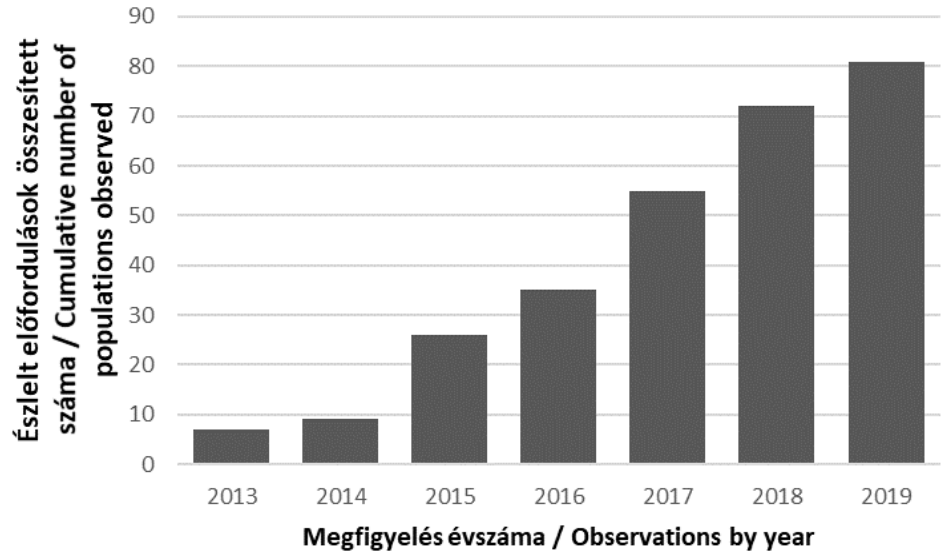

1. ábra A Plantago coronopus előfordulását tartalmazó magyarországi KEF-kvadrátok száma 2013-2019 között

Fig. 1 Observed occurrences of Plantago coronopus between 2013 and 2019, shown in CEU grid cells

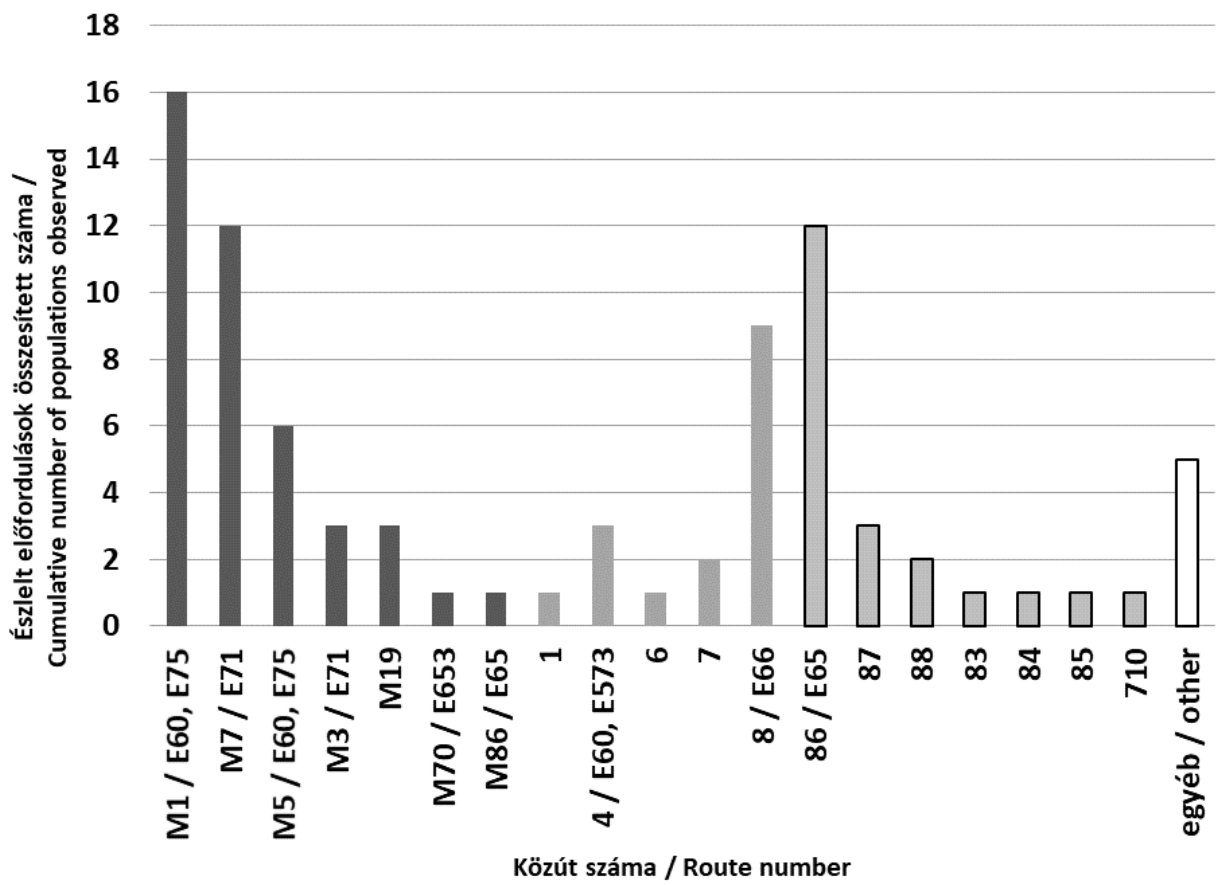

2. ábra Plantago coronopus előfordulások száma a hazai közúthálózaton a KEF-alapmezőnegyed egységeiben

Fig. 2 Occurrences of Plantago coronopus along Hungarian roads, shown in number of CEU grid cells (2019)

Élőhely-igény, ökológiai megfigyelések

A Plantago coronopus hazai előfordulásainak elterjedés-mintázata (3. ábra) alapján egyértelműnek látszik a jelentősen megnövekedett gépjárműforgalom propagulum-terjesztő szerepe. Legnagyobb kiterjedésű és egyedsűrűségű állományai az útpadkák mechanikus és ozmotikus stressztől erősebben érintett (gyakran növényzetmentes) sávja mögötti részén ta- 
lálhatók, gyakran az utat kísérő lejtős árokparton. Az aszfaltcsík szélétől 3 méternél meszszebbre ritkán hatol. A P. coronopus-t GERSTBERGER (2001) útszéli halofitonként tárgyalja. Tapasztalataink alapján a faj terjedés-dinamikája és ökológiája ennél bonyolultabbnak látszik. Habár újabban megfigyelt magyarországi előfordulásainak többsége valóban olyan útpadkákon található, ahol az utak síkosságmentesítésére alkalmazott só közvetlenül felhalmozódik, a megfigyelt állományok között más jellegűek is vannak:

1) a 86-os úton Vámoscsalád belterületén az út szélétől 5 méterre figyeltük meg legszélső példányait, a helyi temető külső szegélygyepjében. Ugyanitt az út padkáján több tíz méter hosszú szakaszon összefüggő állománya található;

2) Vértesszőlősön az út síkjából mintegy $20 \mathrm{~cm}$-re kiemelkedő, gyepes járdasziget gyepjében él;

3) Hasonló körülmények között fordul elő Budakalászon az Auchan parkoló járdaszigetén;

4) Csömörön az Auchan parkoló gyepjében is él (Barina Z. ex litt.).

Ezek a megfigyeléseink egybevágnak azzal, hogy a P. coronopus a Mediterráneumban sem kizárólag sós termőhelyeken él, a litorális és útszéli sós termőhelyen túl mindenféle ruderáliában, szegetáliákban, sziklás helyeken egyaránt jellemző (vö. PIGNATTI 2011, RoTTENSTEINER 2014, Tison et al. 2014, NiKOLIĆ 2015).

\section{Stabilitás, egyéb megfigyelések}

Az állományok stabilitása tekintetében jelentős eltéréseket tapasztaltunk. Legrégebbi (20132014-től ismert) állományai közül az alábbi lelőhelyeken jelenleg is összefüggő tömegben van jelen:

- az M1-es autópálya mentén Győrnél (Arrabona pihenő);

- az M1-es autópálya mentén Ácsnál (Ácsi pihenő);

- a csömöri Auchan áruháznál (Barina Z. ex litt.).

Kisebb állományai ugyanakkor kevésbé stabilak: a 86-87-es főutak Szombathelyt elkerülő közös szakaszán néhány frissen megtelepedett populáció esetében megfigyeltük, hogy az egyedek 1-2 év alatt eltűnnek, ugyanakkor néhány tíz méterrel távolabb újabb populációk jelennek meg. A jelenség feltehetően azzal magyarázható, hogy a megtelepedés első fázisában lévő apró állományok egyedei csekélyebb vitalitásuk, részben kisebb produktivitásuk miatt a hirtelen fellépő mechanikai stressz (taposás, útkarbantartás) miatt nem tudnak szaporodni, és egy-két éves élettartamuk következtében elpusztulnak. Ugyanakkor távolabbi, erős populációk magszórása következtében folyamatosan új propagulumok érkeznek, és alakítanak ki (változó élettartamú) állományokat az arra alkalmas útszéleken.

Megfigyeléseink alapján, néhány esetben a jármüforgalom iránya is befolyásolja új populációk kialakulását. Bizonyos, hogy az M1-es (Mocsa, Tata, Páty) és M7-es autópályán (Fonyód, Balatonlelle, Kajászó), valamint a 8-as úton (Bakonygyepes, Veszprém) feltűnt újabb populációk az út más szakaszain régebb óta jelen lévő, magas egyedszámú állományok (bázispopulációk) magszórása révén jelentek meg.

Érdekességként megemlítjük, hogy a kertészeti kereskedelemben újabban megjelent a faj, több cég „szarvasagancs útifü” néven forgalmazza, és salátaként való fogyasztását ajánlja (Barina Z. ex litt.).

Dolgozatunkban összegeztük a Plantago coronopus terjedését bizonyító adatokat. Egyértelműnek látszik, hogy a taxon a magyarországi közúthálózaton és a vele összeköttetésben lévő, közeli antropogén élőhelyeken sikeresen terjed. A faj megjelenését követő egy évtizeden belül a hazai gyomflóra meghonosodott tagjává vált. 


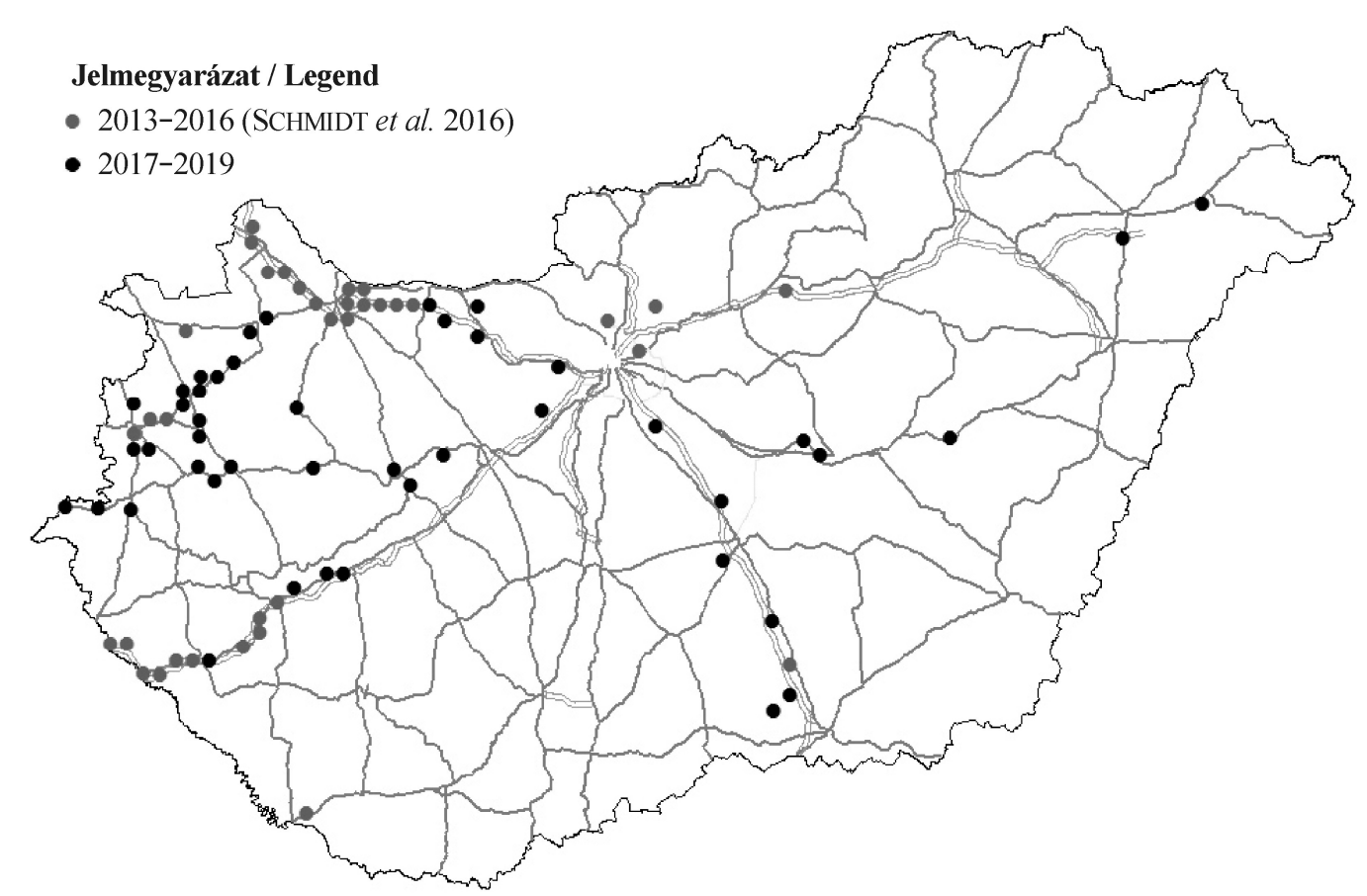

3. ábra A Plantago coronopus elterjedése Magyarországon (2019)

Fig. 3 Distribution of Plantago coronopus in Hungary (2019)

1. táblázat A Plantago coronopus 2013-2019 között megfigyelt KEF-alapú előfordulási adatai a települések alfabetikus sorrendjében

Table 1 Detailed occurrences of Plantago coronopus in Hungary based on Central European Flora Mapping System. Localities are listed alphabetically by settlements

Megfigyelők monogramja / Monograms of the observers: BN - Bauer Norbert, BZ - Barina Zoltán, FR - Fekete Réka, HGy - Haszonits Győző, KD - Kovács Dániel, KG - Király Gergely, LA - Lengyel Attila, MH - Michael Hohla, MVA - Molnár V. Attila, RD - Rolf Diran, SD - Schmidt Dávid, SK - Süveges Kristóf, SZ - Schubert Zoltán, TE - Tóth Endre, WM - Wolf Mátyás

\begin{tabular}{lcccll}
\hline $\begin{array}{c}\text { Település / } \\
\text { Settlement }\end{array}$ & $\begin{array}{c}\text { Út száma / } \\
\text { Route ID }\end{array}$ & $\begin{array}{c}\text { KEF-kvadrát } \\
\text { CEU quadrant }\end{array}$ & $\begin{array}{c}\text { Megfigyelési } \\
\text { idő / Date of } \\
\text { observation }\end{array}$ & $\begin{array}{c}\text { Első } \\
\text { megfigyelö / } \\
\text { First observer }\end{array}$ & Forrás / Source \\
\hline Abony & 4 & 8886.2 & 2018.07 .25 & MVA, SK, FR & $\begin{array}{l}\text { jelen közlemény / } \\
\text { present paper }\end{array}$ \\
\hline Abony & 4 & 8786.3 & 2018.07 .25 & MVA, SK, FR & $\begin{array}{l}\text { jelen közlemény / } \\
\text { present paper }\end{array}$ \\
\hline Ács & M1 & 8373.1 & 2013.10 .19 & SD & SD et al. (2016) \\
\hline Ács & M1 & 8373.2 & 2013.10 .19 & SD & SD et al. (2016) \\
\hline Ajka-Bakonygyepes & 8 & 8871.3 & 2017.10 .17 & SD, HGy & $\begin{array}{l}\text { jelen közlemény / } \\
\text { present paper }\end{array}$ \\
\hline Balástya & M5 & 9585.2 & 2016.07 .07 & SD & SD et al. (2016) \\
\hline Balatonfenyves & 7 & 9270.4 & 2017.09 .15 & BN & $\begin{array}{l}\text { jelen közlemény / } \\
\text { present paper }\end{array}$ \\
\hline Balatonkeresztúr & M7 & 9370.1 & 2015.09 .26 & KG, MH & SD et al. (2016) \\
\hline Balatonlelle & M7 & 9272.1 & 2018.05 .12 & MVA & $\begin{array}{l}\text { jelen közlemény / } \\
\text { present paper }\end{array}$ \\
\hline Barcs & 6 & 0071.1 & 2015.06 .22 & KD & KD \& LA (2015) \\
\hline
\end{tabular}


Kitaibelia 20(1): 19-26.

\begin{tabular}{|c|c|c|c|c|c|}
\hline $\begin{array}{l}\text { Település / } \\
\text { Settlement }\end{array}$ & $\begin{array}{l}\text { Út száma / } \\
\text { Route ID }\end{array}$ & $\begin{array}{l}\text { KEF-kvadrát / } \\
\text { CEU quadrant }\end{array}$ & $\begin{array}{l}\text { Megfigyelési } \\
\text { idő / Date of } \\
\text { observation }\end{array}$ & $\begin{array}{c}\text { Első } \\
\text { megfigyelő / } \\
\text { First observer }\end{array}$ & Forrás / Source \\
\hline Becsehely & M7 & 9566.4 & 2015.09 .26 & KG, MH & SD et al. (2016) \\
\hline Bőny & M1 & 8372.2 & 2013.09 .20 & SD & SD et al. (2016) \\
\hline Börcs & M1 & 8270.4 & 2016.10 .03 & SD & SD et al. (2016) \\
\hline Budakalász & egyéb & 8380.3 & 2016.10 .03 & SD & SD et al. (2016) \\
\hline Csipkerek & 8 & 8867.4 & 2017.09 .06 & SD & SD (2019) \\
\hline Csorna & 86 & 8369.4 & 2019.09 .17 & SD & $\begin{array}{l}\text { jelen közlemény } \\
\text { present paper }\end{array}$ \\
\hline Csömör & egyéb & 8481.3 & 2014.06 .28 & TE, BZ & SD et al. (2016) \\
\hline Csörnyeföld & M70 & 9465.4 & 2013.10 .06 & $\mathrm{KG}, \mathrm{SD}$ & SD et al. (2016) \\
\hline Fertőszentmiklós & 85 & 8467.1 & 2015.06 .18 & SD & SD et al. (2016) \\
\hline Fonyód & M7 & 9271.4 & 2017.07.30 & SD & $\begin{array}{l}\text { jelen közlemény / } \\
\text { present paper }\end{array}$ \\
\hline Gyöngyösfalu & 87 & 8665.4 & 2018.10 .20 & SD & SD (2019) \\
\hline Gyöngyöshalász & M3 & 8285.4 & 2016.06 .22 & KG & SD et al. (2016) \\
\hline Győr & M1 & 8371.4 & 2013.09 .13 & SD & SD et al. (2016) \\
\hline Győr & M1 & 8371.1 & 2013.09 .20 & SD & SD et al. (2016) \\
\hline Győr & M1 & 8372.1 & 2016.10 .03 & SD & SD et al. (2016) \\
\hline Győr & M19 & 8272.3 & 2016.09 .02 & SD & SD et al. (2016) \\
\hline Győr & M19 & 8272.4 & 2016.09 .02 & SD & SD et al. (2016) \\
\hline Győrújbarát & M1 & 8372.3 & 2013.09 .13 & SD & SD et al. (2016) \\
\hline Hegyeshalom & M1 & 8069.3 & 2015.08 .07 & $\mathrm{KG}, \mathrm{RD}$ & SD et al. (2016) \\
\hline Hegyfalu & 86 & 8667.1 & 2017.06 .01 & SD & SD (2019) \\
\hline Inárcs & M5 & 8781.2 & 2018.07.26 & HGy & $\begin{array}{l}\text { jelen közlemény / } \\
\text { present paper }\end{array}$ \\
\hline Jánosháza & 8 & 8868.4 & 2017.09 .06 & SD & SD (2019) \\
\hline Kajászó & M7 & 8678.3 & 2017.10.17 & SD, HGy & $\begin{array}{l}\text { jelen közlemény / } \\
\text { present paper }\end{array}$ \\
\hline Kántorjánosi & M3 & 8098.2 & 2018.09 .26 & FR, SK & $\begin{array}{l}\text { jelen közlemény / } \\
\text { present paper }\end{array}$ \\
\hline Károlyháza & M1 & 8269.2 & 2015.08 .07 & $\mathrm{KG}, \mathrm{RD}$ & SD et al. (2016) \\
\hline Kecskemét & M5 & 9183.4 & 2018.07.25 & MVA, SK, FR & $\begin{array}{l}\text { jelen közlemény / } \\
\text { present paper }\end{array}$ \\
\hline Kisigmánd & M1 & 8374.1 & 2016.10 .03 & SD & SD et al. (2016) \\
\hline Kisújszállás & 4 & 8790.4 & 2018.08.08 & MVA, FR & $\begin{array}{l}\text { jelen közlemény / } \\
\text { present paper }\end{array}$ \\
\hline Lajosmizse & M5 & 8983.3 & 2018.07.25 & MVA, SK, FR & $\begin{array}{l}\text { jelen közlemény / } \\
\text { present paper }\end{array}$ \\
\hline Lébény & M1 & 8270.1 & 2016.10 .03 & SD & SD et al. (2016) \\
\hline Letenye & M7 & 9566.3 & 2015.09 .26 & $\mathrm{KG}, \mathrm{MH}$ & SD et al. (2016) \\
\hline Levél & M1 & 8169.1 & 2015.08 .07 & $\mathrm{KG}, \mathrm{RD}$ & SD et al. (2016) \\
\hline Mocsa & M1 & 8374.2 & 2017.10 .16 & SD, HGy & $\begin{array}{l}\text { jelen közlemény / } \\
\text { present paper }\end{array}$ \\
\hline Nádasd & 8 & 9065.2 & 2018.05 .27 & SZ & SD (2019) \\
\hline Nagykanizsa & 7 & 9568.1 & 2019.06 .03 & SD & $\begin{array}{l}\text { jelen közlemény / } \\
\text { present paper }\end{array}$ \\
\hline Nyíregyháza & M3 & 8196.1 & 2018.04 .24 & MVA & $\begin{array}{l}\text { jelen közlemény / } \\
\text { present paper }\end{array}$ \\
\hline Ordacsehi & egyéb & 9271.2 & 2018.08.17 & SD, WM & $\begin{array}{l}\text { jelen közlemény } \\
\text { present paper }\end{array}$ \\
\hline Páli & 86 & 8568.2 & 2017.06 .24 & SD & $\begin{array}{l}\text { jelen közlemény / } \\
\text { present paper }\end{array}$ \\
\hline
\end{tabular}


SCHMIDT et al. (2020): A csókalábú útifű (Plantago coronopus) folytatódó térhódítása Magyarországon

\begin{tabular}{|c|c|c|c|c|c|}
\hline $\begin{array}{l}\text { Település / } \\
\text { Settlement }\end{array}$ & $\begin{array}{l}\text { Út száma / } \\
\text { Route ID }\end{array}$ & $\begin{array}{l}\text { KEF-kvadrát / } \\
\text { CEU quadrant }\end{array}$ & $\begin{array}{l}\text { Megfigyelési } \\
\text { idő / Date of } \\
\text { observation }\end{array}$ & $\begin{array}{c}\text { Első } \\
\text { megfigyelő / } \\
\text { First observer }\end{array}$ & Forrás / Source \\
\hline Pápa & 83 & 8670.4 & 2017.06.16 & SD & $\begin{array}{l}\text { jelen közlemény / } \\
\text { present paper }\end{array}$ \\
\hline Papkeszi & 710 & 8974.1 & 2018.05 .12 & MVA & $\begin{array}{l}\text { jelen közlemény / } \\
\text { present paper }\end{array}$ \\
\hline Páty & M1 & 8578.2 & 2018.05.11 & MVA & $\begin{array}{l}\text { jelen közlemény / } \\
\text { present paper }\end{array}$ \\
\hline Petőfiszállás & M5 & 9385.3 & 2018.07.26 & MVA, SK, FR & $\begin{array}{l}\text { jelen közlemény / } \\
\text { present paper }\end{array}$ \\
\hline Pósfa & 86 & 8667.3 & 2017.06 .24 & SD & SD (2019) \\
\hline Rátót & 8 & 9064.2 & 2018.07 .06 & SD & SD (2019) \\
\hline Répcelak & 86 & 8568.3 & 2017.06 .24 & SD & SD (2019) \\
\hline Sárvár & 84 & 8767.2 & 2017.06 .03 & SD & SD (2019) \\
\hline Sárvár & 84 & 8767.4 & 2019.08.31 & SD & $\begin{array}{l}\text { jelen közlemény / } \\
\text { present paper }\end{array}$ \\
\hline Sávoly & M7 & 9469.2 & 2015.09 .26 & $\mathrm{KG}, \mathrm{MH}$ & SD et al. (2016) \\
\hline Sormás & M7 & 9567.1 & 2015.09 .26 & $\mathrm{KG}, \mathrm{MH}$ & SD et al. (2016) \\
\hline Sormás & M7 & 9567.2 & 2015.09 .26 & $\mathrm{KG}, \mathrm{MH}$ & SD et al. (2016) \\
\hline Szatymaz & M5 & 9685.2 & 2018.07.26 & MVA, SK, FR & $\begin{array}{l}\text { jelen közlemény / } \\
\text { present paper }\end{array}$ \\
\hline Szegerdő & M7 & 9369.4 & 2015.09 .26 & $\mathrm{KG}, \mathrm{MH}$ & SD et al. (2016) \\
\hline Szentgotthárd & 8 & 9063.2 & 2018.07 .06 & SD & SD (2019) \\
\hline Szilsárkány & 86 & 8469.1 & 2019.09 .17 & SD & $\begin{array}{l}\text { jelen közlemény / } \\
\text { present paper }\end{array}$ \\
\hline Szombathely & 86 & 8765.4 & 2015.09 .13 & SD & SD et al. (2016) \\
\hline Szombathely & 86 & 8865.2 & 2017.07.31 & SD & SD (2019) \\
\hline Táplánszentkereszt & 87 & 8866.1 & 2017.06.22 & SD & $\begin{array}{l}\text { jelen közlemény / } \\
\text { present paper }\end{array}$ \\
\hline Tata & M1 & 8375.3 & 2017.10.16 & SD, HGy & $\begin{array}{l}\text { jelen közlemény / } \\
\text { present paper }\end{array}$ \\
\hline Tatabánya & egyéb & 8476.1 & 2019.09 .06 & $\mathrm{BN}$ & $\begin{array}{l}\text { jelen közlemény / } \\
\text { present paper }\end{array}$ \\
\hline Tornyiszentmiklós & M7 & 9465.3 & 2015.09 .26 & $\mathrm{KG}, \mathrm{MH}$ & SD et al. (2016) \\
\hline Üllés & egyéb & 9685.3 & 2018.07.26 & MVA, SK, FR & $\begin{array}{l}\text { jelen közlemény / } \\
\text { present paper }\end{array}$ \\
\hline Vámoscsalád & 86 & 8667.2 & 2017.05 .25 & SD & SD (2019) \\
\hline Vámoscsalád & 86 & 8567.4 & 2017.05 .25 & SD & SD (2019) \\
\hline Várpalota-Inota & 8 & 8875.1 & 2019.06 .28 & $\mathrm{BN}$ & $\begin{array}{l}\text { jelen közlemény / } \\
\text { present paper }\end{array}$ \\
\hline Vashosszúfalu & 8 & 8968.1 & 2017.09 .06 & SD & SD (2019) \\
\hline Vassurány & 86 & 8766.1 & 2015.08 .03 & SD & SD et al. (2016) \\
\hline Vát & 86 & 8766.2 & 2015.06 .08 & SD & SD et al. (2016) \\
\hline Veresegyház & egyéb & 8381.2 & 2014.09 .06 & LA & KD \& LA (2015) \\
\hline Vértesszőlős & 1 & 8376.3 & 2017.08.30 & $\mathrm{BN}$ & $\begin{array}{l}\text { jelen közlemény / } \\
\text { present paper }\end{array}$ \\
\hline Veszprém & 8 & 8873.4 & 2019.06 .23 & SD & $\begin{array}{l}\text { jelen közlemény / } \\
\text { present paper }\end{array}$ \\
\hline Zalakomár & M7 & 9469.3 & 2015.09 .26 & $\mathrm{KG}, \mathrm{MH}$ & SD et al. (2016) \\
\hline
\end{tabular}




\section{Köszönetnyilvánítás}

Jelen publikáció az „EFOP-3.6.1-16-2016-00018 - A felsőoktatási rendszer K+F+I szerepvállalásának növelése intelligens szakosodás által Sopronban és Szombathelyen" című projekt támogatásával valósult meg. A munkát a K132573 azonosítószámú OTKA pályázat támogatta. Süveges Kristóf munkáját az Új Nemzeti Kiválóság Program (ITM ÚNKP-19-3-I-DE-238) támogatta. Munkánkat Barina Zoltán és Schubert Zoltán levélbeli közlései tették teljesebbé, amiért köszönetünket fejezzük ki.

\section{Irodalom}

DíTĚ D. \& DíTĚTovÁ Z. (2016): Halophytes spreading along roadsides of northern Slovakia. - Thaiszia 26(2): 165-172.

Ehl S., Mildenderger K., FrankenberG T. \& Ries C. (2019): Halophytes in roadside habitats: a survey of salt-tolerant vascular plant species along roads in Luxembourg. - Bulletin de la Société des naturalistes luxembourgeois 121: 37-51.

FEKETE R., MESTERHÁZY A., VALKó O. \& MolnÁR V. A. (2018): A hitchhiker from the beach: the spread of the maritime halophyte Cochlearia danica along salted continental roads. - Preslia 90: 23-37.

FormAn R.T. \& GODRON M. (2003): Road ecology: science and solutions. - Island Press, Covelo, California.

GELBARD J. L. \& BELNAP J. (2003): Roads as conduits for exotic plant invasions in a semiarid landscape. Conservation Biology 17: 420-432.

GERSTBERGER P. (2001): Plantago coronopus subsp. commuttatus als Straßenrandhalophyt eingebürgert in Mitteleuropa. - Tuexenia 21: 249-256.

HoHLA M. (2018): Physalis grisea und Sedum pallidum neu für Österreich sowie weitere Beiträge zur Adventivflora von Österreich. - Stapfia 109: 25-40.

KAPlan Z., KouteckÝ P., DANihelKa J., ŠUMBERovÁ K., DucháčEK M., ŠTĚPÁNKOVÁ J., EKRT L., GRULiCH V., ŘEPKA R., Kubát K., Mráz P., Wild J. \& BRŮna J. (2018): Distributions of vascular plants in the Czech Republic. Part 6. - Preslia 90: 235-346.

KiRÁlY G. \& HoHLA M. (2015): New stage of the invasion: Sporobolus vaginiflorus (Poaceae) reached Hungary. - Studia botanica hungarica 46(2): 149-155.

KovÁcs D. \& Lengyel A. (2015) Adatok a Plantago coronopus L. hazai elterjedéséhez. Kitaibelia 20(2): 306.

NiKLFELD H. (1971): Bericht über die Kartierung der Flora Mitteleuropas. - Taxon 20(4): 545-571.

Nikolić T. (ed.) (2015): Flora Croatica Database (http://hirc.botanic.hr/fcd). - Faculty of Science, University of Zagreb.

Pignatti S. (2011): Flora d'Italia. Volume secondo. - Edagricole, Milano, 732 p.

VAN DER REE R., SMITH D. J. \& GRILO C. (2015): Handbook of road ecology. - Wiley-Blackwell, Oxford.

RotTENSTEINER W. K. (ed.) (2014): Exkursionsflora für Istrien. Verlag des naturwissenschaftlichen Vereins für Kärtnen, Klagenfurt.

ScHмidт D. (2019): Vonalas létesítmények mellett terjedő növények Vas megyében. - Vasi Szemle 73(2): $160-174$.

SCHMidT D., DítĚTovÁ Z., HoRváth A. \& SzÛ́cs P. (2016): Coastal newcomer on motorways: the invasion of Plantago coronopus in Hungary. - Studia botanica hungarica 47(2): 319-344.

ScotT N. E. \& DAvison A. W. (1982): De-icing salt and the invasion of road verges by maritime plants. Watsonia 14: 41-52.

Tison J-M., JAuZEin P. \& Michaud H. (2014): Flore de la France méditerranéenne continentale. - Naturalia Publications, Porquerolles.

Beérkezett / received: 2020. 03. 10. • Elfogadva / accepted: 2020. 04. 07. 